\title{
Diabetes, obesity, and insulin resistance in COVID-19: molecular interrelationship and therapeutic implications
}

\author{
Andrey Santos ${ }^{1}$, Daniéla Oliveira Magro ${ }^{2}$, Rosana Evangelista-Poderoso ${ }^{3}$ and Mario José Abdalla Saad ${ }^{1 *}$
}

\begin{abstract}
Background: Our understanding of the pathophysiology of the COVID-19 manifestations and evolution has improved over the past 10 months, but the reasons why evolution is more severe in obese and diabetic patients are not yet completely understood.

Main text: In the present review we discuss the different mechanisms that may contribute to explain the pathophysiology of COVID-19 including viral entrance, direct viral toxicity, endothelial dysfunction, thromboinflammation, dysregulation of the immune response, and the renin-angiotensin-aldosterone system.

Conclusions: We show that the viral infection activates an integrated stress response, including activations of serine kinases such as PKR and PERK, which induce IRS-1 serine phosphorylation and insulin resistance. In parallel, we correlate and show the synergy of the insulin resistance of COVID-19 with this hormonal resistance of obesity and diabetes, which increase the severity of the disease. Finally, we discuss the potential beneficial effects of drugs used to treat insulin resistance and diabetes in patients with COVID-19.
\end{abstract}

Keywords: COVID-19, Diabetes, Obesity, Insulin resistance, ISR, iDPP4, Metformin

\section{Introduction}

The COVID-19 outbreak, caused by the novel coronavirus (named severe acute respiratory syndrome (SARS) coronavirus 2 (SARS-CoV-2), was first detected at the end of 2019 in Wuhan, China, reached pandemic status in February 2020, and now is present in every country around the world. Our understanding of the pathophysiology of the disease manifestations has improved but the reason why the evolution is more severe in some patients is still unknown. Data coming from different sources has shown that body mass index (BMI) and metabolic syndrome are strong independent risk factors for severe COVID-19 [1, 2]. In the present review we discuss the

*Correspondence: msaad@fcm.unicamp.br

${ }^{1}$ Department of Internal Medicine-FCM, State University of Campinas-

UNICAMP, Campinas, SP, Brazil

Full list of author information is available at the end of the article different mechanisms that may contribute to explain the pathophysiology of COVID-19 including viral entrance, direct viral toxicity, endothelial dysfunction, thromboinflammation, dysregulation of the immune response, and the renin-angiotensin-aldosterone system (RAAS) [1, 2]. Some of these mechanisms are common to sepsis such as the release of cytokines and microcirculation dysfunction, others are specific to COVID-19 such as Angiotensin-converting enzyme 2 (ACE2) mediated viral entry and tissue damage, and dysregulation of the RAAS [3]. In parallel, we correlate these mechanisms with obesity, diabetes, and insulin resistance, which increase the severity of the disease, and the potential beneficial effect of drugs used to treat insulin resistance and diabetes in patients with COVID-19.

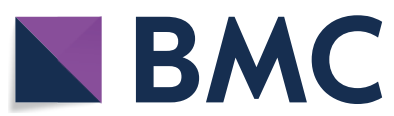

c) The Author(s) 2021. This article is licensed under a Creative Commons Attribution 4.0 International License, which permits use, sharing, adaptation, distribution and reproduction in any medium or format, as long as you give appropriate credit to the original author(s) and the source, provide a link to the Creative Commons licence, and indicate if changes were made. The images or other third party material in this article are included in the article's Creative Commons licence, unless indicated otherwise in a credit line to the material. If material is not included in the article's Creative Commons licence and your intended use is not permitted by statutory regulation or exceeds the permitted use, you will need to obtain permission directly from the copyright holder. To view a copy of this licence, visit http://creativeco mmons.org/licenses/by/4.0/. The Creative Commons Public Domain Dedication waiver (http://creativecommons.org/publicdomain/ zero/1.0/) applies to the data made available in this article, unless otherwise stated in a credit line to the data. 


\section{Pathophysiology}

\section{Viral entrance: ACE2 and DPP4}

The coronavirus entrance into cells is facilitated by its spike protein using ACE2 as an entry receptor, with higher affinity binding. In this process the binding of the spike protein by the cellular serine protease TMPRSS2 [4] is also important, indicating that both ACE2 and TMPRSS2 are key proteins in the process for the virus entrance (Fig. 1a). This is the most accepted mechanism of entrance, but some other considerations have also appeared. Although DPP4 was initially described as receptor for SARS-CoV, which induced Middle East respiratory syndrome (MERS), recently an affinity between DPP4 and the spike (S) receptor-binding domain of SARS-CoV-2 was shown by a bioinformatics approach, indicating that DPP4 is also a potential binding target for SARS-CoV-2 (Fig. 1a).

In addition to upper and lower airways, SARS-CoV-2 also has tropism to renal [5, 6], myocardial [7], neurologic and gastrointestinal [8] tissues, associated with expression of ACE2 and TMPRSS2 in these tissues [911 , suggesting that direct viral tissue damage may occur in these tissues.

\section{Endothelial cell damage and thromboinflammation}

It is now well established that ACE2-mediated entry of SARS-CoV-2 into endothelial cells induces inflammation and the generation of a prothrombotic milieu [1214] (Fig. 1b). These alterations in the set of COVID-19 result in increased thrombin production associated with inhibition of fibrinolysis and activation of complement pathways, a cascade which will lead to microthrombi deposition [14-17]. The cross-talk between platelets and neutrophils and the activation of macrophages have an important role in the proinflammatory effects, characterized by cytokine release, the formation of neutrophil extracellular traps (NETs), and microthrombus deposition [18-22]. Furthermore, acute lung injury can activate a mechanism related to hypoxia-induced hyperviscosity associated with an increase in HIF-1 (hypoxia-inducible
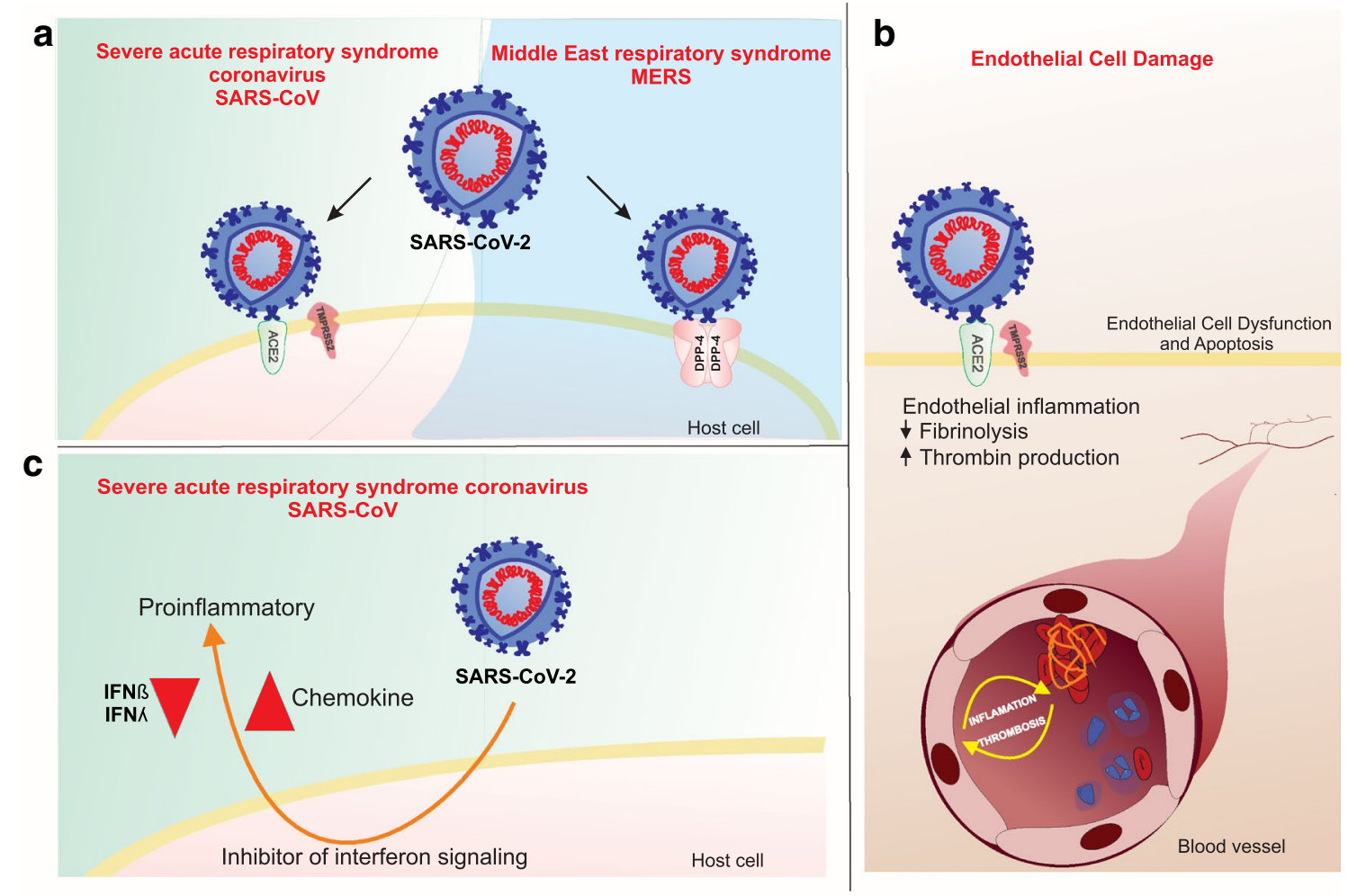

Fig. 1 Pathophysiology. a Viral entrance: ACE2 and DPP4. The coronavirus entrance in cells is facilitated by its spike protein using ACE2. $\mathbf{b}$ Endothelial cell damage and thromboinflammation. ACE2-mediated entry of SARS-CoV-2 in endothelial cells induce inflammation and the generation of a prothrombotic milieu, and results in increased thrombin production associated with inhibition of fibrinolysis and activation of complement pathways, a cascade which will lead to microthrombi deposition. The cross-talk between platelets and neutrophils and the activation of macrophages has an important role in the proinflammatory effects, characterized by cytokine release, the formation of neutrophil extracellular traps (NETs), and microthrombus deposition. c Dysregulation of the immune response. Dysregulation of the immune response of COVID-19, in which there is an increase in cytokine release associated with an attenuation of interferon response 
factor 1) signaling pathway, which can synergically increase the prothrombotic state[1,23].

\section{Dysregulation of the immune response}

Dysregulation of the immune response is a key characteristic of COVID-19, in which there is an increase in cytokine release associated with an attenuation of interferon response, mainly due to $\mathrm{T}$ cell lymphodepletion [24] in parallel with a hyperactivations of innate immunity (Fig. 1c).

The type I and type II interferon receptors are expressed in immune cells and other cell types, and type III interferon receptor is expressed in epithelial cells in the upper and lower respiratory airway. Type I and type II interferons produce a pro-inflammatory response and type III interferons reduce viral replication, induce epithelial barrier stability, and are less inflammatory. In this regard, it is easy to understand why an appropriate interferon response is essential to combat a virus and eliminate a viral infection.

In older persons, in obesity and diabetes there is an impaired early antiviral interferon response, contributing to susceptibility to severe COVID-19 in these individuals. In addition, SARS-CoV-2 infection also potentiates the existing chronic inflammatory state resulting in severe disease.

In other words, in parallel with attenuation of interferon signaling there is a clear activation of neutrophils and monocyte-macrophages which are the main mediators of hyperinflammation $[25,26]$. Neutrophils have a key role in the pathogenesis of COVID19, because SARS-CoV-2 induces infiltration of these cells in the lungs. Necrotic products of cell death as well as neutrophil extracellular traps (NETs) produced during infection activate pattern recognition receptors (PRR), aggravating the cytokine storm $[27,28]$. In addition, NETs can contribute to endothelial dysfunctions and venous thrombosis. In diabetes these effects are potentiated, because hyperglycemia triggers neutrophils to release NETs which in turn contribute to the cytokine storm and sepsis in COVID-19 [29]. This inflammatory state is demonstrated by an increase in serum inflammatory markers such as erythrocyte sedimentation rate, C-reactive protein, ferritin, fibrinogen, D-dimer, and lactate dehydrogenase. Higher levels of these laboratory markers are predictive of subsequent critical illness and mortality in patients with COVID-19 [30-34]. The manifestations related to the immune system and cytokine-release syndrome presented in patients with COVID-19 are illustrated in Fig. 2.

In summary, severe COVID-19 may have a dual pathophysiology: an initially poor antiviral interferon response and an exaggerated inflammatory response, which is not efficient to eliminate the virus. Moreover, diabetes mellitus type 2 (DM2) and obesity, without infections, have an increase in the basal inflammatory response and a potential decrease in an interferon response. Thus, the synergy between COVID-19 and DM2/obesity may amplify the inflammatory response and downregulate even more the interferon response, contributing to more severe disease in these patients (Fig. 2).

There are also modulations of cellular immunity in COVID-19, which can have important clinical implications for long-term immunity. During the acute phase, T cells develop a cytotoxic phenotype that correlates with some clinical and laboratory markers of disease severity described above. In contrast, the convalescent phase of COVID-19 specific T cells behaves as polyfunctional, associated with a stem-like memory phenotype. These data indicate that SARS-CoV-2 elicits a clear and important functional memory $\mathrm{T}$ cell response, suggesting permanent immunity after natural exposure (cell recent) [32-36].

\section{Dysregulation of the RAAS}

Modulations of the RAAS are another piece of the puzzle of the pathophysiological mechanism of COVID-19. The RAAS can be summarized as a cascade of regulatory peptides, peptidases, and receptors that participate in many homeostatic processes of the body, including blood pressure regulation, fluid and electrolyte balance, vascular permeability, and tissue growth [37].

Angiotensin-converting enzyme (ACE) converts angiotensin I (AI) into angiotensin II (AII), which induces vasoconstriction and proliferation. Although ACE2 is not canonically mentioned in this system, this enzyme is a membrane-bound aminopeptidase that counteracts the RAAS pathway. ACE2 cleaves AI and AII into inactive angiotensin 1-9 and angiotensin 1-7, respectively, and the later has vasodilator and antifibrotic effects (Fig. 3).

In experimental diabetes there is an increase in ACE expression in different tissues, which can explain why patients with diabetes may have more severe disease. It is important to mention that the ratio of ACE/ACE2 is increased in the lungs of patients with ARDS, favoring AII generation. SARS-CoV binds and downregulates the expression of ACE2, which is associated with the unopposed action of AII which can have a critical role in lung injury. These data suggest that reducing the ACE/ACE2 ratio may potentially have beneficial effects in lung injury in COVID-19. In this regard many drugs can modulate this ratio with therapeutic implications for patients with obesity and diabetes: insulin reduces ACE2 expression, but GLP-1 agonists, pioglitazone, ACE inhibitors, and statins upregulate $\mathrm{ACE} 2$, reducing the $\mathrm{ACE} / \mathrm{ACE} 2$ ratio [38-44]. 


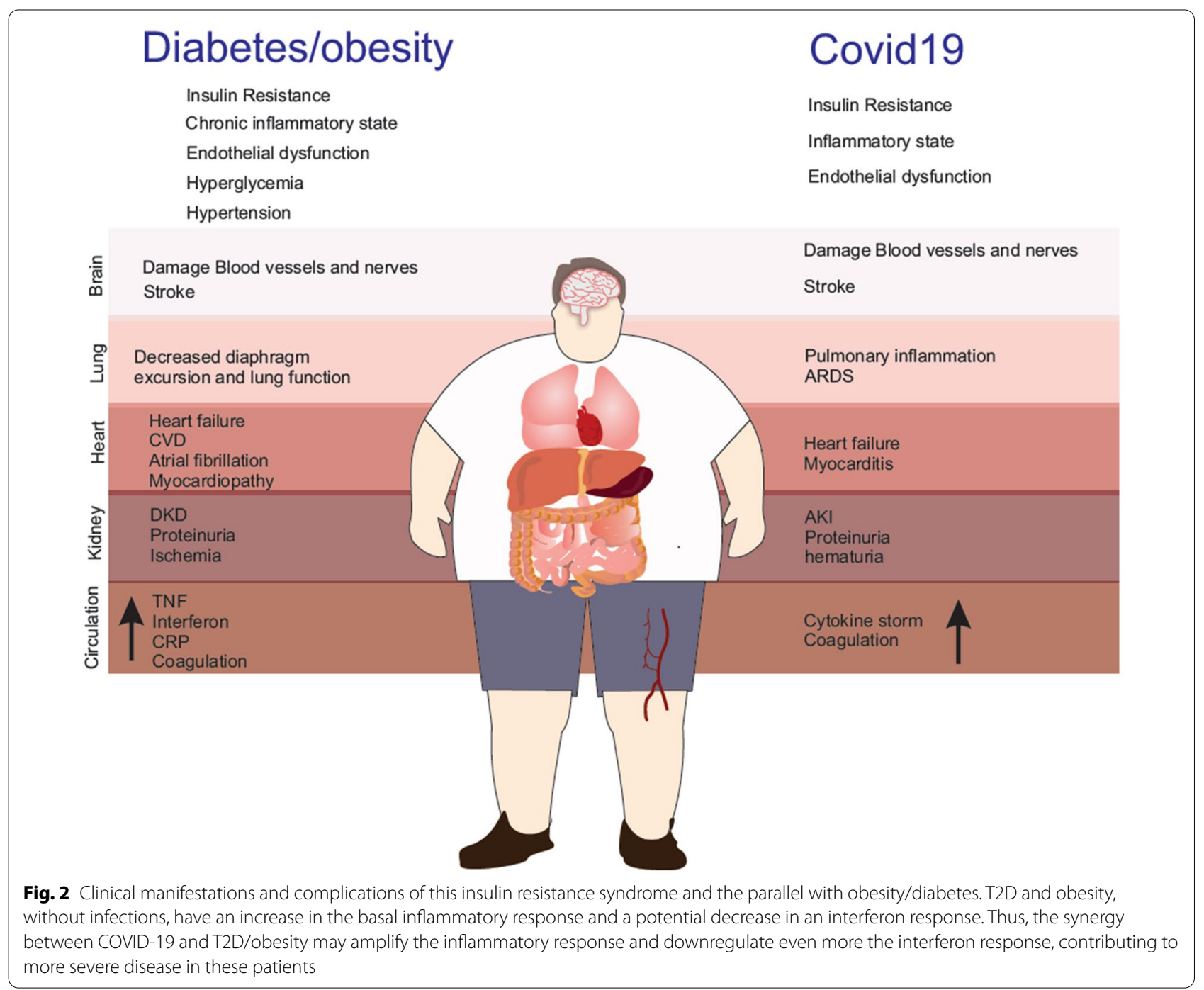

In summary, ACE2 is considered a counter-regulator against ACE because it converts angiotensin II (Ang-II) to Ang-(1-7), preventing the increase in AII. SARS-CoV binds and downregulates the expression of ACE2 and Ang-(1-7), which might increase AII. It is well known that AII has important inflammatory activity, increasing the migration of monocytes and also the infiltration of macrophages [45]. In addition, this leads to loss of protection of endothelial function, because a decrease of counter-regulation of angiotensin II signaling is followed by vascular inflammation and thrombosis of peripheral blood vessels.

\section{Molecular mechanism of insulin resistance in COVID-19: integrated stress response (ISR)}

Recently, stress response at the cellular level was reorganized in a convergent signaling pathway called integrated stress response (ISR), which can be activated by multiple physiological and pathological situations or stressors, including hypoxia, viral infection, and cellintrinsic stresses such as endoplasmic reticulum (ER) stress. The ISR signaling pathway initiates when distinct stressors activate at least one member of a family of four serine/threonine kinases-PKR-like ER kinase (PERK double-stranded RNA-dependent protein kinase (PKR), heme-regulated eIF2a kinase (HRI), and general control non-derepressible 2 (GCN2)-(Fig. 4) [46-48] and these activations will converge to induce phosphorylation of eIF2a on serine. A decrease in protein synthesis is prompted by elF2 phosphorylation and at the same time induces the translation of selected genes, promoting cell survival and recovery [49], but the final response depends on whether the cellular stress is severe or not. If the cellular stress is severe the capacity of the adaptive response to resolve it will be overwhelmed, and other components will be activated to induce cell death. Dephosphorylation 

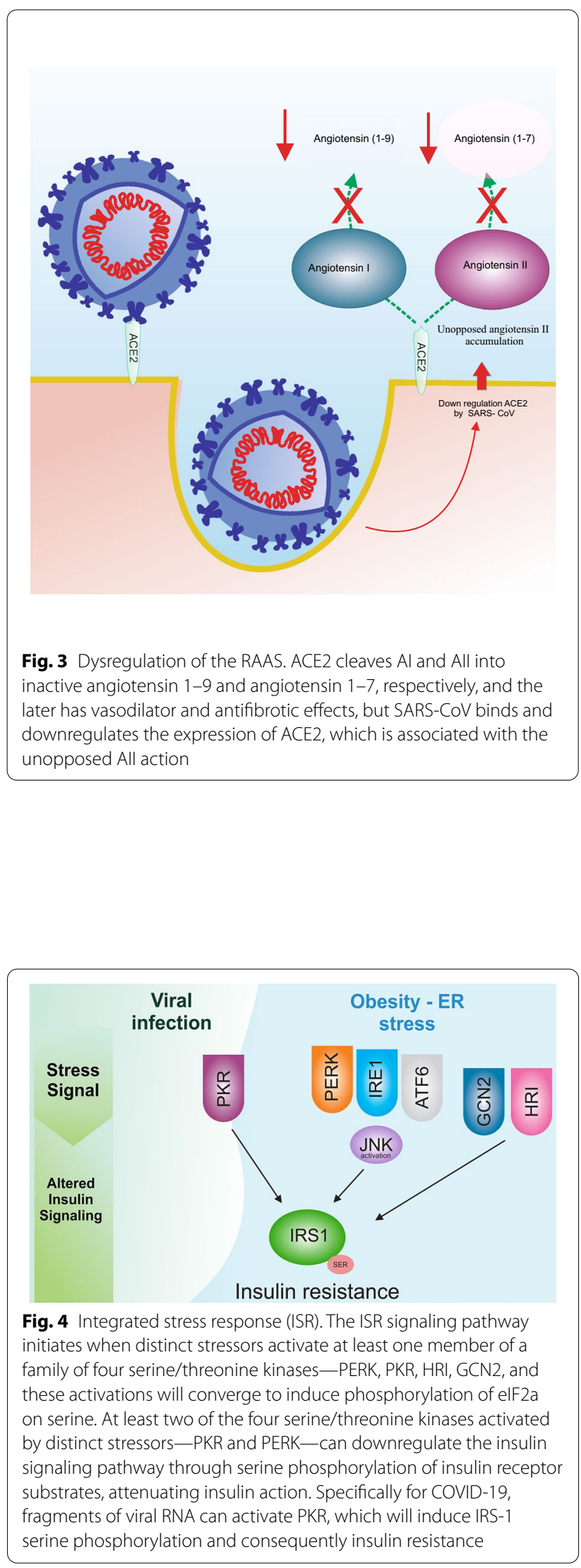

of eIF2a blocks the ISR, normaling the synthesis of the PKR gs2 protein [50-52].

As described, during this ISR, at least two of the four serine/threonine kinases activated by distinct stressorsPKR and PERK-can downregulate the insulin signaling pathway through serine phosphorylation of insulin receptor substrates, attenuating insulin action [53-55]. Specifically for COVID-19, fragments of viral RNA can activate PKR, which will induce IRS-1 serine phosphorylation and consequently insulin resistance. We therefore suggest that insulin resistance always accompanies ISR. Moreover, the cytokine storm and also an increase in hormonal signaling such as AII and cortisol can activate some of the four kinases and contribute to insulin resistance [56]. The clinical manifestations and complications of this insulin resistance syndrome and the parallel with obesity/diabetes are described in Fig. 2.

\section{Insulin resistance induced inflammation}

Although it is well accepted that inflammation in obesity can induce insulin resistance, recent evidence suggests that the opposite is also true, i.e., insulin resistance by itself can also induce inflammation [57]. Insulin resistance in adipose tissue induces macrophage infiltration, developing an inflammatory state. The molecular mechanisms for this relationship are just beginning to be unraveled, but it is important to mention that in the insulin signaling pathway, towards AKT activation there is a serine-threonine protein kinase complex called mTORC2, which is activated by AKT and is an important mediator of insulin action in glucose metabolism and gene expression. One important gene suppressed by mTORC2 in adipose is monocyte chemoattractant protein 1 (MCP1). In this regard, in situations of insulin resistance, the downregulation of insulin signaling with reduced activity of mTORC2 derepresses MCP1 and will attract monocytes to adipose tissue, which will be converted into M1 macrophage [57, 58] (Fig. 5). This data shows that the "chicken-and-egg" relationship of insulin resistance and inflammation is not yet solved. We can thus suggest that inflammation induced by insulin resistance may also be an aggravating mechanism to the cytokine storm observed in Covid-19 patients with obesity.

\section{Insulin resistance, hyperinsulinemia and lung mechanics}

Insulin resistance induces dramatic consequences for health, affecting vessels, heart, brain, and kidneys, however the effects of this hormonal resistance on lung function is only marginally known. Previous data has shown that obesity and fat accumulation in the abdomen pushes up the diaphragm and restricts airflow. Reduced lung volumes subsequently lead to collapse of airways 


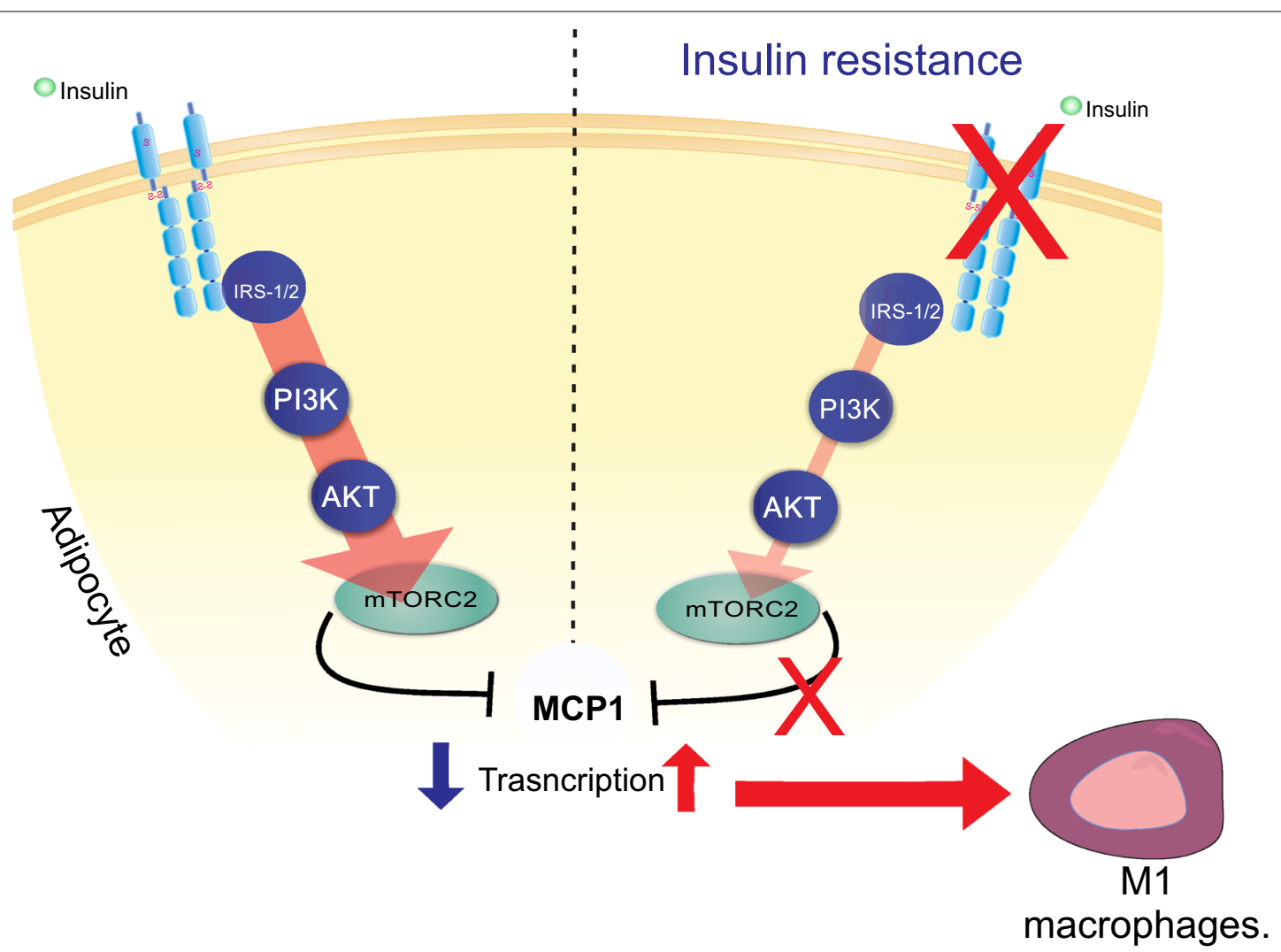

Fig. 5 Insulin resistance induced inflammation. Insulin resistance in adipose tissue induces macrophage infiltration, developing an inflammatory state. In the insulin signaling pathway (IRS-1/2:PI3K:AKT:mTORC2) the MCP1 gene is suppressed by mTORC2 in adipose. In situations of insulin resistance, the downregulation of insulin signaling with reduced activity of MTORC2 will derepress MCP1 and will attract monocytes to adipose tissue, which will be converted into M1 macrophage

in the lower lobes of the lung. This mechanical mechanism is important, but certainly is not the only one. Our laboratory investigated the effect of insulin resistance on mechanical pulmonary parameters and function in animal models of obesity. The consequences of insulin resistance in obesity and DM2 may be secondary to three main mechanisms: chronic inflammation, lack of insulin effect, or hyperinsulinemia [48]. The results of our investigations of lung function in obesity indicated that hyperinsulinemia is the main driver of lung dysfunction. Our results showed that central insulin action is able to control airway reactivity, and in obesity central hyperinsulinemia induces an increased airway hyper-reactivity by stimulating airway-related pre-ganglionic parasympathetic fibers at the dorsal motor nucleus of the vagus (DMV) and nucleus ambiguus (NA). This insulin effect can theoretically be mediated by PI3K/Akt or via ERK signaling, and our results showed that the later pathway accounts completely for this insulin action. It is important to mention that insulin is able to increase all lung mechanical parameters, including tissue resistance (Gtis) and tissue elastance (Htis), indicating that central insulin action modulates both the more calibrous bronchial branches and the very distal bronchioles and lung tissue. We also demonstrated that hyperinsulinemia, independent of body weight, is able to induce bronchoconstriction per se. In summary our data showed that hyperinsulinemia causes airway hyperreactivity in obese mice, through activation of cholinergic nerves in the brain stem, by the ERK signaling pathway. These data have important clinical implications, because in obesity, altered lung mechanics was usually attributed mainly to abdominal compression of the lung, but our data showed that hyperinsulinemia may also have a critical role (Fig. 6).

\section{Similarities and synergy between insulin resistance/ obesity/diabetes and COVID-19}

In symptomatic patients with COVID-19 the course of the disease can be didactically divided into four phases (Fig. 7). Phase 1 starts when an individual becomes symptomatic [59]. The most frequent manifestations in this phase are fever and dry cough, and many individuals 


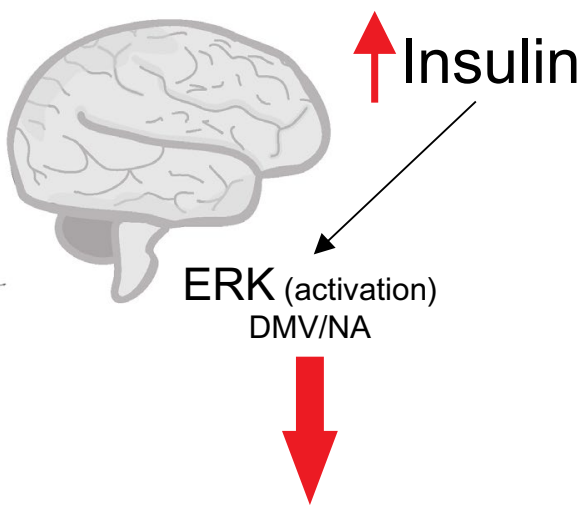

Airway hyperreactivity

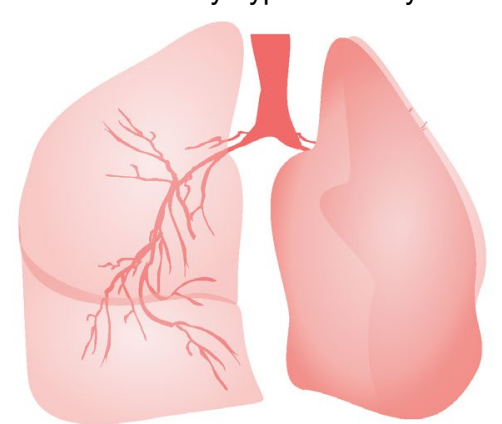

Fig. 6 Airway hyperreactivity. The central insulin action is able to control airway reactivity, and in obesity central hyperinsulinemia induces an increased airway hyper-reactivity by stimulating airway-related pre-ganglionic parasympathetic fibers at the dorsal motor nucleus of the vagus (DMV) and nucleus ambiguous (NA), by the ERK signaling pathway

may lose their senses of taste and smell and feel a general malaise, and for most individuals, the disease is limited to this phase [59]. Phase 2 is the pulmonary stage of the disease [59] when individuals develop pulmonary inflammation and pneumonia. Based on the presence or not of hypoxia this phase can be subdivided into $2 \mathrm{~b}$ or 2a [59]. Most individuals need hospitalization, and some with prolonged hypoxia need mechanical ventilation [59]. When there is progression to phase 3 the patients develop ARDS and extrapulmonary systemic hyper inflammation syndrome, shock, vasoplegia, respiratory failure, cardiopulmonary collapse, myocarditis, and acute kidney injury [59], with poor prognosis and increased mortality. Finally, phase 4 is the recovery and survival stage [60] (Fig. 7).

Data coming from different sources show that loss of metabolic health is the most important risk factor for severe COVID-19, and in this regard DM2, obesity, and hypertension are critical comorbidities in people with COVID-19 [61-63]. There are no simple explanations for these findings which most probably are multifactorial. There are clear similarities and/or synergy between
DM2 and COVID-19 related to mechanism and complications, as described in Fig. 2. At this point it is important to emphasize that metabolic syndrome and DM2 are accompanied by a low chronic inflammatory state, and since COVID-19 also presents a hyperinflammatory response, a synergy between these inflammatory situations may increase the damage induced by inflammatory mediators. In the same line, diabetes and hypertension are risk factors for kidney disease. COVID-19 can also result in kidney injury and patients with diabetes and hypertension are more susceptible to kidney damage during COVID-19 infection. Many other similarities and synergies are presented in Fig. 2.

\section{Hyperglycemia and endocrine pancreas}

Previous data in diabetic patients at hospital admission showed that hyperglycemia was an important predictor of worse outcomes such as ICU admission, mechanical ventilation and death $[64,65]$. Similar results were observed in in-hospital glycemic control, i.e., higher blood glucose levels and bad metabolic control were also associated with worse outcome [66-68]. It is important to mention that SARS-Cov2 can not only impair diabetes control, but can account for some new cases of diabetes. In this regard, this virus tropism for the $\beta$-cell can certainly impair insulin secretion, but can also lead to destruction of $\beta$-cells, inducing new-onset diabetes [69, 70].

The localization of ACE2 expression in the endocrine part of the pancreas suggests that SARS coronavirus enters islets using ACE2 as its receptor and damages islets causing acute diabetes $[71,72]$. However, this is not uniformly accepted because the preferred target for islet viral infection appears to be microvascular structures and ducts, rather than endocrine cells. Regarding the expression of ACE2 in the islets, the studies are contradictory regarding an increase in its expression during the infection of SARS-CoV-2. It seems that this contradiction can occur due to the difficulty of isolating the islets that can affect the expression of ACE2 [71, 73, 74]

\section{Therapeutical implications for metabolic syndrome or diabetes in patients with COVID-19 (Fig. 8)}

The treatment of obese and/or diabetic patients with COVID-19 deserves special considerations, based on recent clinical experience associated with better understanding of pathophysiological mechanisms. For mild COVID-19 the oral glucose-lowering therapies for patients with diabetes could be maintained. In contrast, for inpatients with diabetes and severe COVID-19 the initial indications were to withdrawing ongoing treatments and initiating insulin therapy. It is important to mention that this decision is not a consensus anymore 


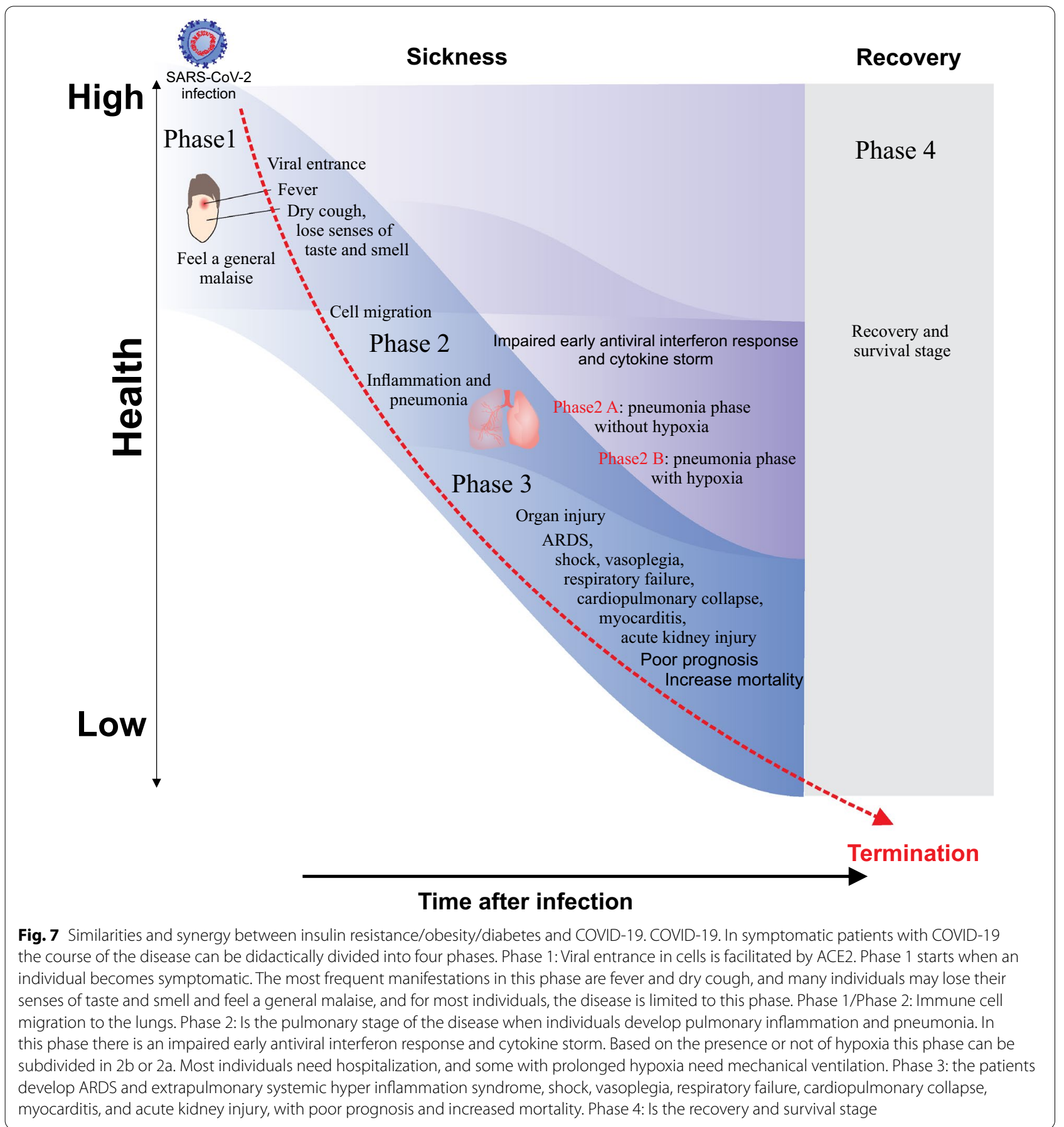

and should be based on the same considerations undertaken for inpatients with diabetes, including severity of associated diseases, nutritional status, glycemic control, and risk of hypoglycemia, hepatic, cardiac, and renal function.

In most studies, DM2 patients with COVID-19 on insulin have shown a worse prognostic, usually attributed to the severity of diabetes in these patients. However, as previously described in experimental models intracerebroventricular-injected insulin increases airway reactivity, lung resistance, and elastance [48]. Thus, it is tempting to speculate that hyperinsulinemia in obesity and diabetes can impair airway reactivity, and that administration of high doses of insulin can worsen this effect, but by lowering the doses of insulin, by association with oral anti-hyperglycemic agents, it is possible 


\section{Recommended to used}

\begin{tabular}{|c|c|c|c|c|c|c|}
\hline Ambulatory & Metformin & iDPP4 & iSGLT2 & Pioglitazone & $\begin{array}{l}\text { GLP1 } \\
\text { analogues }\end{array}$ & Insulin \\
\hline Hospitalized & Metformin & iDPP4 & & Pioglitazone & $\begin{array}{l}\text { GLP1 } \\
\text { analogues }\end{array}$ & Insulin \\
\hline $\begin{array}{l}\text { Hospitalized } \\
\text { ICU }\end{array}$ & & iDPP4 & & & & Insulin \\
\hline
\end{tabular}

Fig. 8 Diabetes treatment in patients with COVID-19. There is no reason to stop metformin therapy during COVID-19 infection unless there are severe gastrointestinal symptoms, or risk of lactic acidosis. Metformin can be a beneficial adjuvant therapy for patients in acute, chronic, and even recovery phases of COVID-19. The continued use of sulfonylurea in stable patients with COVID-19 who are eating regular meals may be justified. However, we need to be alert to any potential risks of hypoglycemia, especially in patients with COVID-19 in intensive care units. A theoretical anti-viral effect of SGLT2-inhibitors was suggested, however caution should be taken when using these drugs because they require hydration and appropriateness of insulin doses to prevent euglycemic ketoacidosis. GLP-1 receptor agonists should be carefully evaluated in severely ill patients with COVID-19 considering their anorexic effects. However, their potential beneficial effects should also be balanced, because these drugs have anti-inflammatory and lung protection actions and can be valuable weapons to combat COVID-19. DPP-4 inhibitors are a group of drugs associated with many advantages, even in severe cases of COVID-19, because they are well tolerated, can be used independent of renal function, and have a low risk of hypoglycemia. In this regard, we should consider recommending a more widespread use of DPP4 inhibitors in diabetic inpatients with severe COVID-19. In most studies, DM2 patients with COVID-19 on insulin have shown a worse prognostic, usually attributed to the severity of diabetes in these patients. However, by lowering the doses of insulin, by association with oral anti-hyperglycemic agents, it is possible to attenuate this potential worse effect of high doses of insulin

to attenuate this potential worse effect of high doses of insulin.

A recent study has shown better clinical outcomes in patients on metformin compared with those on insulin, but again we should consider that the use of insulin may just indicate that the diabetes was more severe and should be interpreted as a potential confounder. Preliminary retrospective data have shown a reduction in death rates in DM2 with COVID-19 hospitalized patients using metformin compared with non-users [75]. Although definitive conclusions can be obtained only by RCTs, based on previous data we can suggest that there is no reason to stop metformin therapy during COVID-19 infection unless there are severe gastrointestinal symptoms, or risk of lactic acidosis. The mechanism by which metformin may protect patients with DM2 and COVID-19 has been attributed at least in part to the effect of the drug that might prevent virus entry into target cells via AMPK activation and the PI3K/Akt signaling pathway [76]. Additionally, metformin also has anti-inflammatory effects that might prevent the cytokine storm [77].

Furthermore, in pre-clinical studies metformin has been shown to improve lung fibrosis, suggesting that this drug should be investigated in the treatment of COVID19-related pulmonary fibrosis [78, 79]. Taken together, all these data support the opinion that metformin can be a beneficial adjuvant therapy for patients in acute, chronic, and even recovery phases of COVID- 19.

Sulphonylureas are associated with an increased risk of hypoglycemia, which can be severe and prolonged [80].
The continued use of sulfonylurea in stable patients with COVID-19 who are eating regular meals may be justified. However, there is an association of sulfonylureas with an increased risk of hypoglycemia, especially in ICU patients with limitations on food intake. In addition, as COVID-19 can cause cardiac injury, caution is recommended in the use of sulfonylureas that have the nonselective binding of sulfonylureas to pancreatic and cardiac sulfonylurea receptors $[81,82]$. Newer drugs such as gliclazide and glimepiride that selectively bind to pancreatic receptors may be safer [83]. Randomized clinical trials are needed to outline a guideline. Clearly, we need to be alert to any potential risks of hypoglycemia, especially in patients with COVID-19 in intensive care units.

A theoretical anti-viral effect of SGLT2-inhibitors (iSGLT2) was suggested, considering that these drugs can increase lactate concentrations and decrease intracellular $\mathrm{pH}$, reducing the viral load [84]. Caution should be taken when using these drugs because they require hydration and appropriateness of insulin doses to prevent euglycemic ketoacidosis.

GLP-1 receptor agonists should be carefully evaluated in severely ill patients with COVID-19 considering their anorexic effects. However, their potential beneficial effects should also be balanced, because these drugs have anti-inflammatory and lung protection actions and can be valuable weapons to combat COVID-19. The anti-inflammatory effects of GLP-1 agonists have been demonstrated in DM2 patients, through reduction in the expression of TNF $\alpha$, IL-1 $\beta$, JNK-1, and decreased IL-6 
concentrations. In addition, in endothelial cells GLP-1 agonists are able to reduce the generation of reactive oxygen species, improving endothelial dysfunction of COVI-19.

DPP-4 inhibitors are a group of drugs associated with many advantages, even in severe cases of COVID-19, because they are well tolerated, can be used independent of renal function, and have a low risk of hypoglycemia. In addition, experimental studies, demonstrated that these drugs can reduce inflammatory response. We now believe that iDPP4 are very safe and can potentially be beneficial to most inpatients with diabetes and COVID19 for the following reasons: (A) Recently, pooled data from three prospective studies in inpatients with DM2 showed that treatment with iDPP4 alone or in combination with basal insulin is effective, and results in a lower incidence of hypoglycemia and in the use of lower doses of insulin compared to a basal bolus insulin regimen [85]. (B) In addition, recent data has demonstrated an affinity between DPP4 and the spike (S) receptor-binding domain of SARS-CoV-2, by a bioinformatics approach, indicating that DPP4 is a potential binding target for SARS-CoV-2 [86]. This study points to DPP4 as a binding target for SARS-CoV-2 and reinforces DPP4 as a very promising target to attenuate COVID-19 severity.

Finally, there are now six studies [2, 87-91] (Table 1) that have investigated the effects of DPP4 inhibitors on the outcomes of COVID-19 in diabetic patients. Three retrospective studies had a small number of patients on iDPP4, but despite this, Rhee et al. [90] demonstrated that the fatality rates and ventilation scores of patients treated with DDP4i were lower than those of diet alone treated DM2 patients. The Coronado study showed no independent association between severity of COVID-19 and use of DPP4 inhibitors, but we should emphasize that they only considered iDPP4 use prior to admission. Recently, in a preprint manuscript Rhee et al. showed a significant beneficial effect of iDPP4 on primary outcomes. More importantly, very recently an Italian group showed in a case-control study that in patients with type 2 diabetes, sitagliptin treatment at the time of the hospitalization reduced mortality and improved clinical outcome [92]. Although only a randomized trial can definitively answer this question (use of DPP4 inhibitors in patients with COVID-19), based on molecular, pathophysiological, and retrospective studies, the use of iDPP4 is safe, and is certainly beneficial in metabolic control and can probably reduce the severity of COVID-19. In this regard, we should consider recommending a more widespread use of DPP4 inhibitors in diabetic inpatients with severe COVID-19.

It is well established that peroxisome proliferator-activated receptor-gamma (PPAR- $\gamma$ ) is abundantly expressed in immune cell macrophages and is a blocker of macrophage activation and $\mathrm{T}$ cell responses [93]. Pioglitazone, a PPAR- $\gamma$ ligand, through action in monocytes and macrophage, is able to reduce the secretion of TNF- $\alpha$, IL-1 $\beta$, and IL-6 [94]. This drug reduces lung injury and decreases mortality from sepsis by reducing inflammatory cytokine production. In addition, pioglitazone

Table 1 Clinical studies that reported DPP-4 inhibitors in patients with T2DM and COVID-19

\begin{tabular}{|c|c|c|c|c|c|c|c|}
\hline $\begin{array}{l}\text { First author; year; } \\
\text { Country }\end{array}$ & Simple size & T2M (n.\%) & DPP-4 i (n.\%) & Age (years) ${ }^{a}$ & Male (\%) & Outcomes & In-hospital death (n.\%) \\
\hline \multicolumn{8}{|l|}{ Retrospective studies } \\
\hline $\begin{array}{l}\text { Chen et al. } 2020 . \\
\text { China [87] }\end{array}$ & 904 & $136(15.0)$ & $20(14.7)$ & $66.0(56.0-73.0)$ & $N R$ & $\begin{array}{l}\text { Hospital stay (days) } \\
22(19.3-29.0)\end{array}$ & $5(25.0)$ \\
\hline $\begin{array}{l}\text { Xu et al. } 2020 . \\
\text { China [88] }\end{array}$ & 364 & $114(31.3)$ & $7(6.1)$ & $66.0(57-73)$ & 54.4 & Lower ventilation score & $7(100.0)$ \\
\hline $\begin{array}{l}\text { Zhu et al. } 2020 . \\
\text { China [89] }\end{array}$ & 7337 & $952(12.9)$ & $55(6.8)$ & $N R$ & $N R$ & $20 \%$ well controlled & - \\
\hline $\begin{array}{l}\text { Rhee et al. } 2020 . \\
\text { South Korea [90] }\end{array}$ & 5080 & $832(16.3)$ & $263(31.6)$ & $63.69(12.2)$ & 56.65 & Intensive care $3.42 \%$ & 4.39 \\
\hline \multicolumn{8}{|c|}{ Multicenter observational study } \\
\hline $\begin{array}{l}\text { Cariou et al. } 2020 . \\
\text { France [2] }\end{array}$ & 1317 & $1166(88.5)$ & $285(21.6)$ & $69.8(13.0)$ & 64.9 & $\begin{array}{l}\text { Tracheal intubation and/ } \\
\text { or death within } 7 \text { days } \\
\text { of admission } \\
\text { OR } 1.01(0.75,1.34)\end{array}$ & $\begin{array}{l}\text { OR } \\
0.85(0.55,1.32)\end{array}$ \\
\hline \multicolumn{8}{|l|}{ Case-control study } \\
\hline $\begin{array}{l}\text { Fadini et al. } 2020 \\
\text { Italy [91] }\end{array}$ & 403 & $85(21.1)$ & $9(10.6)$ & $72.2(12.8)$ & 77.8 & $\begin{array}{l}\text { ICU admittance } 33.3 \% \\
\text { Semi-intensive care } \\
\quad 44.4 \%\end{array}$ & 11.1 \\
\hline
\end{tabular}

NR No reported, ICU intensive care unit

a Age was reported as range; median $\pm S D$ 
Table 2 COVID-19 mortality according diabetes or without diabetes

\begin{tabular}{|c|c|c|c|c|c|c|}
\hline & \multirow[t]{2}{*}{ Study type } & \multirow[t]{2}{*}{ Population (n.) } & \multirow[t]{2}{*}{ With diabetes n. (\%) } & \multicolumn{3}{|c|}{ Covid-19 mortality } \\
\hline & & & & $\begin{array}{l}\text { With diabetes } \\
\text { n. (\%) }\end{array}$ & $\begin{array}{l}\text { Without diabetes } \\
\text { n. (\%) }\end{array}$ & P-value or $\mathrm{RR}^{*}$ \\
\hline Zhang et al. [97] & Retrospective & 258 & $63(24)$ & $7(11.1)$ & $8(4.1)$ & 0.039 \\
\hline Zhou et al. [30] & Retrospective & 191 & $36(19)$ & $17(31)$ & $19(14)$ & 0.0051 \\
\hline Zhu et al. [89] & Retrospective & 7337 & $952(13)$ & $74(7.8)$ & $174(2.7)$ & $<0.001$ \\
\hline Yan et al. [98] & Retrospective & 193 & $48(25)$ & $39(81.3)$ & $69(47.6)$ & $<0.001$ \\
\hline Barron et al. [99] & Cohort-study & $61,414,470$ & $2,864,670(4.7)$ & $7434(31.4)$ & $15,831(0.02)$ & $2.03(1.97-2.09)^{*}$ \\
\hline
\end{tabular}

$R R^{*}$ relative risk

upregulates ACE2 expression, supporting the control of ongoing inflammation, as previously described [95].

It is important to mention that the anti-inflammatory and glucose lowering activities of pioglitazone are two distinct effects induced by different pathways. In this regard, a low dose of pioglitazone is able to reduce TNF $\alpha$ and IL-6 levels without side effects [96]. We can thus speculate that $15 \mathrm{mg}$ of pioglitazone seems to be a treatment option to produce anti-inflammatory effects for COVID-19 patients.

In conclusion, this review presents different mechanisms that may contribute to explain the pathophysiology of COVID-19 including viral entrance, direct viral toxicity, endothelial dysfunction, thromboinflammation, dysregulation of the immune response, and the reninangiotensin-aldosterone system. Moreover, we show that the viral infection activates an ISR, including activations of serine kinases such as PKR and PERK, which will induce IRS-1 serine phosphorylation and insulin resistance. In parallel, we correlate and show synergy of the insulin resistance of COVID-19 with this hormonal resistance of obesity and diabetes, which increase the severity of the disease (Table 2). Finally, we discuss the potential beneficial effect of drugs used to treat insulin resistance and diabetes in patients with COVID-19, emphasizing the beneficial role of metformin, iDPP4, and pioglitazone (Fig. 8)

\section{Acknowledgements}

This review is dedicated to the memory of Jósimo Pinheiro.

\section{Authors' contributions}

MJAS, AS, DOM and REP_critical revision of the manuscript; MJAS and AS drafted the article. All authors read and approved the final manuscript.

\section{Funding}

INCT (National Institute of Science and Technology for Diabetes and Obesity) 465693/2014-8.

\section{Availability of data and materials}

Not applicable.

Ethics approval and consent to participate

Not applicable.
Consent for publication

Not applicable.

\section{Competing interests}

The authors declare that they have no competing interests

\section{Author details}

1 Department of Internal Medicine-FCM, State University of CampinasUNICAMP, Campinas, SP, Brazil. ${ }^{2}$ Department of Surgery, Faculty of Medical Sciences, State University of Campinas-UNICAMP, Campinas, SP, Brazil. ${ }^{3}$ Faculty of Medical Sciences, State University of Campinas-UNICAMP, Campinas, SP, Brazil.

Revised: 5 February 2021 Accepted: 13 February 2021

Published online: 01 March 2021

\section{References}

1. Gupta A, Madhavan MV, Sehgal K, Nair N, Mahajan S, Sehrawat TS, Bikdeli B, Ahluwalia N, Ausiello JC, Wan EY, et al. Extrapulmonary manifestations of COVID-19. Nat Med. 2020;26(7):1017-32.

2. Cariou B, Hadjadj S, Wargny M, Pichelin M, Al-Salameh A, Allix I, Amadou C, Arnault G, Baudoux F, Bauduceau B, et al. Phenotypic characteristics and prognosis of inpatients with COVID-19 and diabetes: the CORONADO study. Diabetologia. 2020;63(8):1500-15.

3. Li H, Liu L, Zhang D, Xu J, Dai H, Tang N, Su X, Cao B. SARS-CoV-2 and viral sepsis: observations and hypotheses. Lancet. 2020;395(10235):1517-20.

4. Hoffmann M, Kleine-Weber H, Schroeder S, Krüger N, Herrler T, Erichsen S, Schiergens TS, Herrler G, Wu NH, Nitsche A, et al. SARS-CoV-2 cell entry depends on ACE2 and TMPRSS2 and Is blocked by a clinically proven protease inhibitor. Cell. 2020;181(2):271-80.e278.

5. Puelles VG, Lütgehetmann M, Lindenmeyer MT, Sperhake JP, Wong MN, Allweiss L, Chilla S, Heinemann A, Wanner N, Liu S, et al. Multiorgan and renal tropism of SARS-CoV-2. N Engl J Med. 2020;383(6):590-2.

6. Su H, Yang M, Wan C, Yi LX, Tang F, Zhu HY, Yi F, Yang HC, Fogo AB, Nie $X$, et al. Renal histopathological analysis of 26 postmortem findings of patients with COVID-19 in China. Kidney Int. 2020;98(1):219-27.

7. Tavazzi G, Pellegrini C, Maurelli M, Belliato M, Sciutti F, Bottazzi A, Sepe PA, Resasco T, Camporotondo R, Bruno R, et al. Myocardial localization of coronavirus in COVID-19 cardiogenic shock. Eur J Heart Fail. 2020;22(5):911-5

8. Xiao F, Tang M, Zheng X, Liu Y, Li X, Shan H. Evidence for gastrointestinal infection of SARS-CoV-2. Gastroenterology. 2020;158(6):1831-3.e1833.

9. Qi F, Qian S, Zhang S, Zhang Z. Single cell RNA sequencing of 13 human tissues identify cell types and receptors of human coronaviruses. Biochem Biophys Res Commun. 2020;526(1):135-40.

10. Ziegler CGK, Allon SJ, Nyquist SK, Mbano IM, Miao VN, Tzouanas CN, Cao Y, Yousif AS, Bals J, Hauser BM, et al. SARS-CoV-2 receptor ACE2 is an interferon-stimulated gene in human airway epithelial cells and is detected in specific cell subsets across tissues. Cell. 2020;181(5):1016-35. e1019. 
11. Pan XW, Xu D, Zhang H, Zhou W, Wang LH, Cui XG. Identification of a potential mechanism of acute kidney injury during the COVID-19 outbreak: a study based on single-cell transcriptome analysis. Intensive Care Med. 2020;46(6):1114-6.

12. Ackermann M, Verleden SE, Kuehnel M, Haverich A, Welte T, Laenger F, Vanstapel A, Werlein C, Stark H, Tzankov A, et al. Pulmonary vascular endothelialitis, thrombosis, and angiogenesis in Covid-19. N Engl J Med. 2020;383(2):120-8.

13. Teuwen LA, Geldhof $\vee$, Pasut A, Carmeliet P. COVID-19: the vasculature unleashed. Nat Rev Immunol. 2020;20(7):389-91.

14. Varga Z, Flammer AJ, Steiger $P$, Haberecker $M$, Andermatt R, Zinkernagel AS, Mehra MR, Schuepbach RA, Ruschitzka F, Moch H. Endothelial cell infection and endotheliitis in COVID-19. Lancet. 2020;395(10234):1417-8.

15. Engelmann B, Massberg S. Thrombosis as an intravascular effector of innate immunity. Nat Rev Immunol. 2013;13(1):34-45.

16. Levi M, van der Poll T. Coagulation and sepsis. Thromb Res. 2017;149:38-44.

17. Jackson SP, Darbousset R, Schoenwaelder SM. Thromboinflammation: challenges of therapeutically targeting coagulation and other host defense mechanisms. Blood. 2019:133(9):906-18.

18. Koupenova M, Corkrey HA, Vitseva O, Manni G, Pang CJ, Clancy L, Yao C, Rade J, Levy D, Wang JP, et al. The role of platelets in mediating a response to human influenza infection. Nat Commun. 2019;10(1):1780.

19. Semple JW, Italiano JE, Freedman J. Platelets and the immune continuum. Nat Rev Immunol. 2011;11(4):264-74.

20. Merad M, Martin JC. Pathological inflammation in patients with COVID19: a key role for monocytes and macrophages. Nat Rev Immunol. 2020;20(6):355-62.

21. Yeaman MR. Platelets in defense against bacterial pathogens. Cell Mol Life Sci. 2010;67(4):525-44.

22. Bikdeli B, Madhavan MV, Gupta A, Jimenez D, Burton JR, Der Nigoghossian C, Chuich T, Nouri SN, Dreyfus I, Driggin E, et al. Pharmacological agents targeting thromboinflammation in COVID-19: review and implications for future research. Thromb Haemost. 2020;120(7):1004-24.

23. Gupta N, Zhao YY, Evans CE. The stimulation of thrombosis by hypoxia. Thromb Res. 2019;181:77-83.

24. Kim KD, Zhao J, Auh S, Yang X, Du P, Tang H, Fu YX. Adaptive immune cells temper initial innate responses. Nat Med. 2007;13(10):1248-52.

25. Channappanavar R, Perlman S. Pathogenic human coronavirus infections: causes and consequences of cytokine storm and immunopathology. Semin Immunopathol. 2017;39(5):529-39.

26. Huang KJ, Su IJ, Theron M, Wu YC, Lai SK, Liu CC, Lei HY. An interferon-gamma-related cytokine storm in SARS patients. J Med Virol. 2005;75(2):185-94.

27. Tomar B, Anders HJ, Desai J, Mulay SR. Neutrophils and neutrophil extracellular traps drive necroinflammation in COVID-19. Cells. 2020;9(6):1383.

28. Zuo Y, Yalavarthi S, Shi H, Gockman K, Zuo M, Madison JA, Blair C, Weber A, Barnes BJ, Egeblad M, et al. Neutrophil extracellular traps in COVID-19. JCl Insight. 2020;5(11):e138999.

29. Wong SL, Demers M, Martinod K, Gallant M, Wang Y, Goldfine AB, Kahn CR, Wagner DD. Diabetes primes neutrophils to undergo NETosis, which impairs wound healing. Nat Med. 2015;21(7):815-9.

30. Zhou F, Yu T, Du R, Fan G, Liu Y, Liu Z, Xiang J, Wang Y, Song B, Gu X, et al. Clinical course and risk factors for mortality of adult inpatients with COVID-19 in Wuhan, China: a retrospective cohort study. Lancet. 2020;395(10229):1054-62.

31. Ruan Q, Yang K, Wang W, Jiang L, Song J. Clinical predictors of mortality due to COVID-19 based on an analysis of data of 150 patients from Wuhan, China. Intensive Care Med. 2020;46(5):846-8.

32. Petrilli CM, Jones SA, Yang J, Rajagopalan H, O'Donnell L, Chernyak Y, Tobin KA, Cerfolio RJ, Francois F, Horwitz LI. Factors associated with hospital admission and critical illness among 5279 people with coronavirus disease 2019 in New York City: prospective cohort study. BMJ. 2020;369:m1966

33. Cummings MJ, Baldwin MR, Abrams D, Jacobson SD, Meyer BJ, Balough EM, Aaron JG, Claassen J, Rabbani LE, Hastie J, et al. Epidemiology, clinical course, and outcomes of critically ill adults with COVID-19 in New York City: a prospective cohort study. Lancet. 2020;395(10239):1763-70.

34. Wu C, Chen X, Cai Y, Xia J, Zhou X, Xu S, Huang H, Zhang L, Du C, Zhang Y, et al. Risk factors associated with acute respiratory distress syndrome and death in patients with coronavirus disease 2019 pneumonia in Wuhan, China. JAMA Intern Med. 2020;180(7):934-43.

35. Zhou F. Clinical course and risk factors for mortality of adult inpatients with COVID-19in Wuhan, China: a retrospective cohort study. Lancet. 2020;395:1054-62.

36. Ruan Q, Yang K, Wang W, Jiang L, Song J. Clinical predictors of mortality due to COVID-19 based on an analysis of data of 150 patients from Wuhan,\&nbsp;China. Intensive Care Med. 2020;46:846-8.

37. Vaduganathan M, Vardeny $O$, Michel T, McMurray JJV, Pfeffer MA, Solomon SD. Renin-angiotensin-aldosterone system inhibitors in patients with Covid-19. N Engl J Med. 2020;382(17):1653-9.

38. Gilliam-Davis S, Gallagher PE, Payne VS, Kasper SO, Tommasi EN, Westwood BM, Robbins ME, Chappell MC, Diz DI. Long-term systemic angiotensin II type 1 receptor blockade regulates mRNA expression of dorsomedial medulla renin-angiotensin system components. Physiol Genomics. 2011:43(13):829-35.

39. Lovren F, Pan Y, Quan A, Teoh H, Wang G, Shukla PC, Levitt KS, Oudit GY, Al-Omran M, Stewart DJ, et al. Angiotensin converting enzyme-2 confers endothelial protection and attenuates atherosclerosis. Am J Physiol Heart Circ Physiol. 2008;295(4):H1377-84.

40. Mizuiri S, Aoki T, Hemmi H, Arita M, Sakai K, Aikawa A. Urinary angiotensin-converting enzyme 2 in patients with CKD. Nephrology (Carlton). 2011;16(6):567-72.

41. Sodhi CP, Wohlford-Lenane C, Yamaguchi Y, Prindle T, Fulton WB, Wang S, McCray PB, Chappell M, Hackam DJ, Jia H. Attenuation of pulmonary ACE2 activity impairs inactivation of des-Arg. Am J Physiol Lung Cell Mol Physiol. 2018;314(1):L17-31.

42. Vuille-dit-Bille RN, Camargo SM, Emmenegger L, Sasse T, Kummer E, Jando J, Hamie QM, Meier CF, Hunziker S, Forras-Kaufmann Z, et al. Human intestine luminal ACE2 and amino acid transporter expression increased by ACE-inhibitors. Amino Acids. 2015;47(4):693-705.

43. Xu H, Zhong L, Deng J, Peng J, Dan H, Zeng X, Li T, Chen Q. High expression of ACE2 receptor of 2019-nCoV on the epithelial cells of oral mucosa. Int J Oral Sci. 2020;12(1):8.

44. Sánchez-Aguilar M, Ibarra-Lara L, Del Valle-Mondragón L, Rubio-Ruiz ME, Aguilar-Navarro AG, Zamorano-Carrillo A, Ramírez-Ortega MDC, PastelínHernández G, Sánchez-Mendoza A. Rosiglitazone, a ligand to PPAR Y, Improves blood pressure and vascular function through renin-angiotensin system regulation. PPAR Res. 2019;2019:1371758.

45. Montezano AC, Nguyen Dinh Cat A, Rios FJ, Touyz RM. Angiotensin II and vascular injury. Curr Hypertens Rep. 2014;16(6):431.

46. Wek RC, Jiang HY, Anthony TG. Coping with stress: elF2 kinases and translational control. Biochem Soc Trans. 2006;34(Pt 1):7-11.

47. Donnelly N, Gorman AM, Gupta S, Samali A. The elF2a kinases: their structures and functions. Cell Mol Life Sci. 2013;70(19):3493-511.

48. Leiria LOS, Arantes-Costa FM, Calixto MC, Alexandre EC, Moura RF, Folli F, Prado CM, Prado MA, Prado VF, Velloso LA, et al. Increased airway reactivity and hyperinsulinemia in obese mice are linked by ERK signaling in brain stem cholinergic neurons. Cell Rep. 2015;11(6):934-43.

49. Lu PD, Harding HP, Ron D. Translation reinitiation at alternative open reading frames regulates gene expression in an integrated stress response. J Cell Biol. 2004;167(1):27-33.

50. Nagahara N, Yoshii T, Abe Y, Matsumura T. Thioredoxin-dependent enzymatic activation of mercaptopyruvate sulfurtransferase. An intersubunit disulfide bond serves as a redox switch for activation. J Biol Chem. 2007;282(3):1561-9.

51. Novoa I, Zeng H, Harding HP, Ron D. Feedback inhibition of the unfolded protein response by GADD34-mediated dephosphorylation of elF2alpha. J Cell Biol. 2001;153(5):1011-22.

52. Novoa I, Zhang Y, Zeng H, Jungreis R, Harding HP, Ron D. Stress-induced gene expression requires programmed recovery from translational repression. EMBO J. 2003;22(5):1180-7.

53. Hirata AE, Alvarez-Rojas F, Carvalheira JB, Carvalho CR, Dolnikoff MS, Abdalla Saad MJ. Modulation of IR/PTP1B interaction and downstream signaling in insulin sensitive tissues of MSG-rats. Life Sci. 2003:73(11):1369-81.

54. Zanotto TM, Quaresma PG, Guadagnini D, Weissmann L, Santos AC, Vecina JF, Calisto K, Santos A, Prada PO, Saad MJ. Blocking iNOS and endoplasmic reticulum stress synergistically improves insulin resistance in mice. Mol Metab. 2017:6(2):206-18. 
55. Saad MJ, Folli F, Araki E, Hashimoto N, Csermely P, Kahn CR. Regulation of insulin receptor, insulin receptor substrate-1 and phosphatidylinositol 3-kinase in 3T3-F442A adipocytes. Effects of differentiation, insulin, and dexamethasone. Mol Endocrinol. 1994;8(5):545-57.

56. Bezerra RM, Ueno M, Silva MS, Tavares DQ, Carvalho CR, Saad MJ, Gontijo JA. A high-fructose diet induces insulin resistance but not blood pressure changes in normotensive rats. Braz J Med Biol Res. 2001;34(9):1155-60.

57. Shimobayashi M, Albert V, Woelnerhanssen B, Frei IC, Weissenberger D, Meyer-Gerspach AC, Clement N, Moes S, Colombi M, Meier JA, et al. Insulin resistance causes inflammation in adipose tissue. J Clin Invest. 2018;128(4):1538-50.

58. Huang SC, Smith AM, Everts B, Colonna M, Pearce EL, Schilling JD, Pearce EJ. Metabolic reprogramming mediated by the mTORC2-IRF4 signaling axis is essential for macrophage alternative activation. Immunity. 2016;45(4):817-30.

59. Siddiqi HK, Mehra MR. COVID-19\&nbsp;illness in native and immunosuppressed states: a clinical-therapeutic staging proposal. J Heart Lung Transplant. 2020;39(5):405-7.

60. Ayres JS. Immunometabolism of infections. Nat Rev Immunol. 2020;20(2):79-80.

61. Wang D. Clinical characteristics of 138 hospitalized patients with 2019 novel coronavirus-infected pneumonia in Wuhan, China. J Am Med Assoc. 2020;323:1061-1069.

62. Zhang JJ, Dong X, Cao YY, Yuan YD, Yang YB, Yan YQ, Akdis CA, Gao YD Clinical characteristics of 140 patients infected with SARS-CoV-2 in Wuhan, China. Allergy. 2020;75(7):1730-41.

63. Deng SQ, Peng HJ. Characteristics of and public health responses to the coronavirus disease 2019 outbreak in China. J Clin Med. 2020;9(2):575.

64. lacobellis G, Penaherrera CA, Bermudez LE, Bernal Mizrachi E. Admission hyperglycemia and radiological findings of SARS-CoV2 in patients with and without diabetes. Diabetes Res Clin Pract. 2020;164:108185.

65. Zhang Y, Li H, Zhang J, Cao Y, Zhao X, Yu N, Gao Y, Ma J, Zhang H, Guo X, et al. The clinical characteristics and outcomes of patients with diabetes and secondary hyperglycaemia with coronavirus disease 2019: a singlecentre, retrospective, observational study in Wuhan. Diabetes Obes Metab. 2020;22(8):1443-54.

66. Wang F, Yang Y, Dong K, Yan Y, Zhang S, Ren H, Yu X, Shi X. Clinical characteristics of 28 patients with diabetes and Covid-19 in Wuhan, China. Endocr Pract. 2020;26(6):668-74.

67. Rayman G, Lumb A, Kennon B, Cottrell C, Nagi D, Page E, Voigt D, Courtney $\mathrm{H}$, Atkins $\mathrm{H}$, Platts J, et al. Guidance on the management of Diabetic Ketoacidosis in the exceptional circumstances of the COVID-19 pandemic. Diabet Med. 2020;37(7):1214-6.

68. Kim NY, Ha E, Moon JS, Lee YH, Choi EY. Acute hyperglycemic crises with coronavirus disease-19: case reports. Diabetes Metab J. 2020;44(2):349-53.

69. Tian S. Pulmonary pathology of early-phase novel coronavirus (COVID19) pneumonia in two patients with lung cancer. J Thorac Oncol. 2020;15:700-4

70. Chee YJ, Ng SJH, Yeoh E. Diabetic ketoacidosis precipitated by Covid-19 in a patient with newly diagnosed diabetes mellitus. Diabetes Res Clin Pract. 2020;164:108166.

71. Hikmet F, Méar L, Edvinsson Å, Micke P, Uhlén M, Lindskog C. The protein expression profile of ACE2 in human tissues. Mol Syst Biol. 2020;16(7):e9610.

72. Nam SY, Seo HH, Park HS, An S, Kim JY, Yang KH, Kim CS, Jeong M, Jin YW. Phosphorylation of CLK2 at serine 34 and threonine 127 by AKT controls cell survival after ionizing radiation. J Biol Chem. 2010;285(41):31157-63.

73. Yang JK, Lin SS, Ji XJ, Guo LM. Binding of SARS coronavirus to its receptor damages islets and causes acute diabetes. Acta Diabetol. 2010;47(3):193-9.

74. Fignani D, Licata G, Brusco N, Nigi L, Grieco GE, Marselli L, Overbergh L, Gysemans C, Colli ML, Marchetti P, et al. SARS-CoV-2 receptor angiotensin l-converting enzyme type 2 (ACE2) is expressed in human pancreatic. Front Endocrinol (Lausanne). 2020;11:596898.

75. Scheen AJ. Metformin and COVID-19: from cellular mechanisms to reduced mortality. Diabetes Metab. 2020;46:423-6.

76. Sharma S, Ray A, Sadasivam B. Metformin in COVID-19: a possible role beyond diabetes. Diabetes Res Clin Pract. 2020;164:108183.
77. Hariyanto TI, Kurniawan A. Metformin use is associated with reduced mortality rate from coronavirus disease 2019 (COVID-19) infection. Obes Med. 2020;19:100290.

78. Rangarajan S, Bone NB, Zmijewska AA, Jiang S, Park DW, Bernard K, Locy ML, Ravi S, Deshane J, Mannon RB, et al. Metformin reverses established lung fibrosis in a bleomycin model. Nat Med. 2018;24(8):1121-7.

79. Chen JY, Qiao K, Liu F, Wu B, Xu X, Jiao GQ, Lu RG, Li HX, Zhao J, Huang J, et al. Lung transplantation as therapeutic option in acute respiratory distress syndrome for coronavirus disease 2019-related pulmonary fibrosis. Chin Med J (Engl). 2020;133(12):1390-6.

80. Schopman JE, Simon AC, Hoefnagel SJ, Hoekstra JB, Scholten RJ, Holleman $F$. The incidence of mild and severe hypoglycaemia in patients with type 2 diabetes mellitus treated with sulfonylureas: a systematic review and meta-analysis. Diabetes Metab Res Rev. 2014;30(1):11-22.

81. Lippi G, Lavie CJ, Sanchis-Gomar F. Cardiac troponin I in patients with coronavirus disease 2019 (COVID-19): evidence from a meta-analysis. Prog Cardiovasc Dis. 2020;63(3):390-1.

82. Bansal M. Cardiovascular disease and COVID-19. Diabetes Metab Syndr. 2020;14(3):247-50.

83. Zeller M, Danchin N, Simon D, Vahanian A, Lorgis L, Cottin Y, Berland J, Gueret P, Wyart P, Deturck R, et al. Impact of type of preadmission sulfonylureas on mortality and cardiovascular outcomes in diabetic patients with acute myocardial infarction. J Clin Endocrinol Metab. 2010;95(11):4993-5002.

84. Cure E, Cumhur Cure M. Can dapagliflozin have a protective effect against COVID-19 infection? A hypothesis. Diabetes Metab Syndr. 2020;14(4):405-6.

85. Lorenzo-González C, Atienza-Sánchez E, Reyes-Umpierrez D, Vellanki P, Davis GM, Pasquel FJ, Cardona S, Fayfman M, Peng L, Umpierrez GE. Safety and efficacy of DDP4-inhibitors for management of hospitalized general medicine and surgery patients with type 2 diabetes. Endocr Pract. 2020. https://doi.org/10.4158/EP-2019-0481.

86. Li Y, Zhang Z, Yang L, Lian X, Xie Y, Li S, Xin S, Cao P, Lu J. The MERS-CoV receptor DPP4 as a candidate binding target of the SARS-CoV-2 spike. iscience. 2020;23(8):101400.

87. Chen Y, Yang D, Cheng B, Chen J, Peng A, Yang C, Liu C, Xiong M, Deng A, Zhang Y, et al. Clinical characteristics and outcomes of patients with diabetes and COVID-19 in association with glucose-lowering medication. Diabetes Care. 2020;43(7):1399-407.

88. Xu Z, Wang Z, Wang S, Ye Y, Luo D, Wan L, Yu A, Sun L, Tesfaye S, Meng $Q$, et al. The impact of type 2 diabetes and its management on the prognosis of patients with severe COVID-19. J Diabetes. 2020. https://doi. org/10.1111/1753-0407.13084.

89. Zhu L, She ZG, Cheng X, Qin JJ, Zhang XJ, Cai J, Lei F, Wang H, Xie J, Wang W, et al. Association of blood glucose control and outcomes in patients with COVID-19 and pre-existing Type 2 Diabetes. Cell Metab. 2020;31(6):1068-77.e1063.

90. Rhee SY, Lee J, Nam H, Kyoung D-S, Kim DJ. Effects of a DPP-4 inhibitor and RAS blockade on clinical outcomes of patients with diabetes and COVID-19. medRxiv. 2020:2020.2005.2020.20108555.

91. Fadini GP, Morieri ML, Longato E, Bonora BM, Pinelli S, Selmin E, Voltan G, Falaguasta D, Tresso S, Costantini G, et al. Exposure to dipeptidyl-peptidase-4inhibitors and COVID-19 among people with type 2 diabetes: a case-control study. Diabetes Obes Metab. 2020. https://doi.org/10.1111/ dom.14097.

92. Solerte SB, D'Addio F, Trevisan R, Lovati E, Rossi A, Pastore I, Dell'Acqua M, Ippolito E, Scaranna C, Bellante R, et al. Sitagliptin treatment at the time of hospitalization was associated with reduced mortality in patients with type 2 diabetes and COVID-19: a multicenter, case-control, retrospective\& nbsp;observational study. Diabetes Care. 2020:43:2999-3006.

93. Kock G, Bringmann A, Held SA, Daecke S, Heine A, Brossart P. Regulation of dectin-1-mediated dendritic cell activation by peroxisome proliferator-activated receptor-gamma ligand troglitazone. Blood. 2011;117(13):3569-74.

94. Chen Y, Niu Z, Cui J, Shen P. The inhibitory effect of troglitazone on macrophage differentiation mediated by repressing NF-KB activation independently of PPARY. 2014;10(3):261-8.

95. Zhang $W, X u Y Z$, Liu B, Wu R, Yang YY, Xiao XQ, Zhang X. Pioglitazone upregulates angiotensin converting enzyme 2 expression in insulin-sensitive tissues in rats with high-fat diet-induced nonalcoholic steatohepatitis. ScientificWorldJournal. 2014;2014:603409. 
96. Mohapatra J, Sharma M, Singh S, Chatterjee A, Swain P, Balaraman $R$, Patel PR, Jain MR. Subtherapeutic dose of pioglitazone reduces expression of inflammatory adipokines in $\mathrm{db} / \mathrm{db}$ mice. Pharmacology. 2009;84(4):203-10.

97. Zhang Y, Cui Y, Shen M, Zhang J, Liu B, Dai M, Chen L, Han D, Fan Y, Zeng Y, et al. Association of diabetes mellitus with disease severity and prognosis in COVID-19: a retrospective cohort study. Diabetes Res Clin Pract. 2020;165:108227.

98. Yan Y, Yang Y, Wang F, Ren H, Zhang S, Shi X, Yu X, Dong K. Clinical characteristics and outcomes of patients with severe covid-19 with diabetes. BMJ Open Diabetes Res Care. 2020;8(1):e001343.
99. Barron E, Bakhai C, Kar P, Weaver A, Bradley D, Ismail H, Knighton P, Holman N, Khunti K, Sattar N, et al. Associations of type 1 and type 2 diabetes with COVID-19-related mortality in England: a whole-population study. Lancet Diabetes Endocrinol. 2020;8(10):813-22.

\section{Publisher's note}

Springer Nature remains neutral with regard to jurisdictional claims in published maps and institutional affiliations.
Ready to submit your research? Choose BMC and benefit from:

- fast, convenient online submission

- thorough peer review by experienced researchers in your field

- rapid publication on acceptance

- support for research data, including large and complex data types

- gold Open Access which fosters wider collaboration and increased citations

- maximum visibility for your research: over 100M website views per year

At BMC, research is always in progress.

Learn more biomedcentral.com/submissions 